\title{
ENVIRONMENTAL AND OCCUPATIONAL HEALTH RISKS AMONG AGRICULTURAL WORKERS LIVING IN A RURAL COMMUNITY NEAR PETROLEUM REFINERY AND MOTORWAY IN SKOPJE REGION
}

\author{
Jovanka KARADŽINSKA-BISLIMOVSKA, Jordan MINOV, Sašo STOLESKI, \\ Dragan MIJAKOSKI, Snežana RISTESKA-KUC, and Snežana MILKOVSKA \\ Institute for Occupational Health of Republic of Macedonia, WHO Collaborating Center Skopje, \\ Republic of Macedonia
}

Received in May 2010

Accepted in July 2010

\begin{abstract}
To assess health risks in agricultural workers associated with environmental exposure to pollutants released from a petroleum refinery and from traffic, we performed a cross-sectional study that included 119 randomly selected subjects divided in two groups. Group 1 included 60 agricultural workers living in a rural community near the petroleum refinery and a motorway overpass, whereas Group 2 consisted of 59 agricultural workers performing similar activities and living in a rural community with no exposure to industrial and traffic pollutants. Risk assessment included a questionnaire, blood pressure measurement, spirometry, laboratory tests, and toxicological analysis. The groups showed a similar prevalence of health problems, with exception of muscle pain in the extremities, headache, and fatigue, which were significantly more common in Group 1. Diastolic blood pressure was higher in Group 1, but not significantly ( $\mathrm{p}=0.057$ ). The same is true for blood carbon monoxide. Significantly higher in Group 1 were blood haemoglobin $(\mathrm{p}=0.001)$ and blood lead $(\mathrm{p}<0.001)$. Serum cholinesterase activity was similar in both groups. Our findings indicate the need of regular medical exams, ambient monitoring and environmental impact assessment in agricultural population in order to detect individuals at risk and to institute adequate preventive measures.
\end{abstract}

KEY WORDS: blood pressure, environmental exposure, haemoglobin, rural environment, toxicological analysis

Agriculture is one of the most common occupations and a relevant income source for the rural population in the Republic of Macedonia (1). Activities span from pig, cattle, and poultry farming to crop processing and packaging, irrigation, pest management, grain storage, fishery, manure handling and associated domestic activities. The latest 2007 census of agriculture in Macedonia estimated that 662,000 ha of land was cultivated (1). Even though about $40 \%$ of Macedonian population is rural (1), there are few data about their health, or more specifically of agricultural workers.
Agriculture is usually described as one of the most hazardous occupations worldwide. According to the International Labour Office (ILO), from a total of 330,000 fatal workplace accidents worldwide, about 170,000 agricultural workers lose their lives to occupational accidents (2). Working environment in agriculture involves exposure to physical and mechanical hazards (tractors, harvesters and other machinery, noise, weather, terrain, fire), chemical hazards (pesticides and other agrochemicals, fertilisers, dust, fuel, nitrogen dioxide, carbon monoxide), 
biological hazards (animals, microorganisms such as bacteria, fungi, viruses, and parasites). Some of their injuries are caused by, ergonomic factors (repetitive motion, weight lifting). Moreover, stress and psychological disorders are also frequent (2). The most common occupational diseases in agricultural sector are muscular-skeletal disorders, respiratory and allergic diseases, and pesticide poisoning, but they are still underreported $(2,3)$. The incidence of occupational cancers in agricultural workers is lower than in the general population, although this is not true for specific cancers such as melanoma and lip cancers (4).

The living and working conditions in rural settings are not strictly separated, and some of the registered diseases in agricultural workers could be related to the unhealthy life-style, living conditions and environment, and not to the workplace itself (4).

Agricultural workers living in rural communities with exposure to industrial and traffic pollutants face combined effects of specific environmental and occupational risks. This article reports the risks associated with this kind of combined exposure in a rural community of the broader Skopje area, which is located near a petroleum refinery and motorway E-75.

Petroleum refineries release large amounts of chemicals and hazardous air pollutants, including benzene, toluene, ethylbenzene, xylene, particulate matter, lead, nitrogen oxides, carbon monoxide, hydrogen sulphide, and sulphur dioxide, natural gas, and volatile fuels and oils. These pollutants can cause nausea, eye problems, headaches, respiratory, neurological, developmental and reproductive disorders, birth defects, skin irritations, and cancers (5-7).

Several epidemiological studies have examined the effects of exposure to road vehicle traffic on chronic respiratory and allergic diseases and have also reported that living in close proximity to major roads is associated with an increased risk of wheezing $(8,9)$.

Air pollution is related to morbidity and mortality of several diseases, such as coronary heart disease (10), Hodgkin's disease (11), exacerbation of chronic respiratory symptoms and increased mortality from chronic obstructive pulmonary disease (12).

Despite the presence of relevant occupational and environmental risks in rural environments, their impact on agricultural workers' health and the related burden of diseases in our country are not always estimated properly. A step forward in this direction is the implementation of the Preventive Programme for the Assessment of Health Status and Work Ability in Agricultural Workers in the Republic of Macedonia that started last year with scientific epidemiological research in about 3000 agricultural workers, using a specially designed questionnaire. This programme is supported by Macedonian Ministry of Health and implemented by the Institute for Occupational Health of the Republic of Macedonia (IOHM) as a WHO Collaborating Centre.

This paper reports on the environmental and occupational health risks in agricultural workers exposed to industrial and traffic pollutants by living in rural community near petroleum refinery and highway E-75, in the Skopje region.

\section{METHODS}

\section{Study design}

Our cross-sectional study was conducted on site by a team from IOHM (Skopje, Republic of Macedonia) in May and June 2009. This article brings a part of research results obtained within the Training and Research in Environmental Health in the Balkan (TREHB) project supported by Michigan State University (MSU) Institute of International Health (IIH) and funded through a grant from the National Institutes of Health's Fogarty International Center, USA.

The study was performed in two stages. The first included completion of a specially designed questionnaire on occupational and environmental risks and the second phase included blood pressure measurement, spirometry, laboratory and toxicological analyses.

\section{Study subjects}

We examined 119 randomly selected agricultural workers divided in two groups. The first group included 60 subjects aged 27 to 74 years, living in a rural community of Miladinovci, located near a petroleum refinery $(300 \mathrm{~m}$ to $500 \mathrm{~m})$ and near a cross-roads and a motorway overpass (300 $\mathrm{m}$ to 500 $\mathrm{m})$. The second group included 59 subjects with similar demographic characteristics living in a rural community of Creshevo, located $21 \mathrm{~km}$ from the petroleum refinery and the motorway overpass, with no exposure to industrial and traffic pollutants.

Agriculture was the primary occupation in both groups. Usually the whole family was involved in 
agricultural activities, which included cultivating vegetables such as tomato, pepper, potato, and cabbage and breeding cattle, domestic animals, and poultry. All study subjects gave their informed consent before entering the study.

\section{Questionnaire}

An interviewer-led questionnaire was completed by all subjects. The questionnaire included items on demographics, work history (occupation, workplace, duration of exposure, and total duration of employment, previous workplace, if any, and duration, hazards at the workplace, work organization and use of preventive measures), health problems and their workrelatedness, smoking status (active smoker, duration of smoking, number of cigarettes per day, ex-smoker, non-smoker), and alcohol consumption (quantity and frequency).

The health status of the examined subjects was assessed by questions about skin problems (redness, itching, rush), nasal symptoms (sneezing, itching, runny nose, blocked nose), respiratory symptoms (cough, phlegm, dyspnoea, wheezing, chest tightness), cardiovascular problems (arterial hypertension, heart attacks), gastrointestinal symptoms (abdominal pain, nausea, vomiting, diarrhoea, constipation), osteomuscular problems (back pain, neck pain, muscle pain in the extremities, paraesthesia), and other symptoms (headache, dizziness, fatigue, insomnia, anxiety).

\section{Blood pressure measurement}

Blood pressure (BP) was measured using a mercurial sphygmomanometer (Bokang, China) according to current recommendations (13).

\section{Spirometry}

Forced vital capacity (FVC), forced expiratory volume in one second $\left(\mathrm{FEV}_{1}\right), \mathrm{FEV}_{1} / \mathrm{FVC}$ ratio, and maximal expiratory flow at $50 \%, 25 \%$, and $25 \%$ to $75 \%$ of FVC $\left(\mathrm{MEF}_{50}, \mathrm{MEF}_{25}\right.$, and $\mathrm{MEF}_{25-75}$, respectively), were measured in all subjects using the Ganshorn SanoScope LF8 spirometer (Ganshorn Medizin Electronic GmbH, Germany). We recorded only the best result from three $\mathrm{FEV}_{1}$ measurements that were within $5 \%$ of each other. Spirometry results are expressed as percentages of the predicted values according to the European Community for Coal and Steel (ECCS) norms (14).

\section{Laboratory analyses}

Blood haemoglobin concentration and erythrocyte count were determined using an automatic analyzer (Nihon Kohden, Celltac $\alpha$, MEK 6400, Japan).

\section{Toxicological analyses}

Venous blood (about $2 \mathrm{~mL}$ ) was taken into a sterile vacutainer with $1.5 \mathrm{mg} \mathrm{mL}^{-1}$ of $\mathrm{K}_{2}$ EDTA and stored in a portable refrigerator at $+4{ }^{\circ} \mathrm{C}$. Blood lead level (BLL) was determined using the LeadCare II Blood Lead Test System (ESA Biosciences, Chelmsford, USA) (15).

Blood CO was determined a micromethod (16) in which sulphuric acid extracts $\mathrm{CO}$ from whole blood (16). The extracted $\mathrm{CO}$ reacts with a solution of palladium chloride, reducing palladium into elementary form. The excess of unreduced palladium chloride is determined by spectrophotometry at $420 \mathrm{~nm}$. Blood CO concentration is proportional to the difference between the added amount of palladium chloride and the measured amount after reduction.

Serum cholinesterase activity was determined using spectrophotometry with benzoylthiocholine iodide (17). Serum cholinesterase dissolves the substrate butyrylthiocholine iodide into butyric acid and alcohol - thiocholine. Reacting with dithionitrobenzoic acid, the released alcohol forms a coloured complex, which is determined by spectrophotometry at $412 \mathrm{~nm}$.

\section{Statistical analysis}

The results were analysed with descriptive and inferential statistical methods using STATISTICA 7 for Windows. Descriptive statistical analysis included tables and figures containing data series according to defined variables. Continuous variables were expressed as means \pm standard deviation (SD) and nominal variables as numbers and percentages. The chi-square test (or Fisher's exact test where appropriate) was used for testing differences in frequency. Comparison of the means was performed by independent-samples $t$-test. A $p$-value of less than 0.05 was considered statistically significant.

\section{RESULTS AND DISCUSSION}

Table 1 shows the demographics of the study subjects. Both groups performed similar agricultural activities (Table 2) and claimed similar exposure (Table 3). 
Table 1 Demographics of the study subjects

\begin{tabular}{lcc}
\hline Variable & $\begin{array}{c}\text { Group 1 - Miladinovci } \\
(\mathbf{n = 6 0 )}\end{array}$ & $\begin{array}{c}\text { Group 2 - Creshevo } \\
(\mathbf{n = 5 9 )}\end{array}$ \\
\hline Sex (M/F ratio) & 1.4 & 1.1 \\
Age / years & $58.8 \pm 11.8$ & $59.4 \pm 1.1$ \\
BMI / kg m ${ }^{-2}$ & $25.7 \pm 3.5$ & $26.1 \pm 3.4$ \\
& & \\
Daily smokers & $14(23.3 \%)$ & $12(20.3 \%)$ \\
Duration of smoking / years & $10.8 \pm 11.5$ & $11.2 \pm 11.8$ \\
Ex-smokers & $7(11.7 \%)$ & $8(13.6 \%)$ \\
& & \\
Alcohol consumption & $9(15.0 \%)$ & $8(13.6 \%)$ \\
\hline
\end{tabular}

Numerical data are expressed as means with standard deviation, frequencies as number and percentage.

M: male; F: female; BMI: body mass index

Table 2 Agricultural activities of examined subjects

\begin{tabular}{lccc}
\hline Agricultural activity & $\begin{array}{c}\text { Group 1 - Miladinovci } \\
(\mathbf{n = 6 0 )}\end{array}$ & $\begin{array}{c}\text { Group 2 - Creshevo } \\
\mathbf{( n = 5 9 )}\end{array}$ & p-value* \\
& $\mathbf{N}(\mathbf{\%})$ & $56(94.9)$ & 0.892 \\
Cultivating vegetables & $59(98.3)$ & $0(0)$ & 0.323 \\
Cultivating cereals & $1(1.7)$ & $6(10.2)$ & 0.814 \\
Cultivating fruits & $7(11.7)$ & $56(94.9)$ & 0.892 \\
Planting & $59(98.3)$ & $57(96.6)$ & 0.894 \\
Digging (sapping) & $60(100)$ & $1(0.2)$ & 0.333 \\
Weeding & $3(0.5)$ & $15(25.4)$ & 0.785 \\
Mechanisation use & $17(28.3)$ & $54(91.5)$ & 0.838 \\
Irrigation & $52(86.7)$ & $45(76.2)$ & 0.417 \\
Pesticide use & $57(95.0)$ & $45(76.3)$ & 0.923 \\
Cattle-breeding & $47(78.3)$ & $13(22.1)$ & 0.299 \\
Milking & $20(33.3)$ & $35(59.3)$ & 0.375 \\
Stall settling & $46(76.7)$ & & \\
\hline
\end{tabular}

Data are expressed as number $(N)$ and percentage.

* Tested by chi-square test (or Fisher's exact test where appropriate).

The prevalence of health problems was similar in both groups, with the exception of muscle pain in the extremities, headache, and fatigue, whose prevalence was significantly higher in Group 1 (the Miladinovci group) (Table 4). Work-relatedness of symptoms was reported by both groups (Table 5).

The mean systolic pressure was not significantly higher in the Miladinovci group than in the Creshevo group ( $\mathrm{p}=0.124$; independent-samples $t$-test), and the difference in mean diastolic pressure between the two groups just missed statistical significance $(\mathrm{p}=0.057$; independent-samples $t$-test) (Figure 1). Table 6 shows spirometry results. We did not found significant differences between two study groups. Blood haemoglobin was significantly higher in the Miladinovci group $(\mathrm{p}=0.001$; independent-samples $t$ test) (Figure 2), whereas the difference between mean
RBC counts was not significant (figure not shown). Similarly, mean BLL was also significantly higher in the Miladinovci ( $\mathrm{p}<0.001$; independent-samples $t$ test) (Figure 3). Mean blood carbon monoxide in the Miladinovci group was higher than in the Creshevo group, but the difference was not significant (Figure 4). Mean serum cholinesterase activity was similar in both groups (Figure 5).

Our results confirmed earlier reports which suggest that people exposed to industrial and traffic pollutants experience some health disorders more frequently than those living in unpolluted rural communities. Exposure to a mixture of heavy metals, pesticides, gases, and other chemical additives increases the risk of acute and chronic adverse reactions, such as headache and rash. The risk is cumulative with time and may lead to the development of chronic diseases (18). 


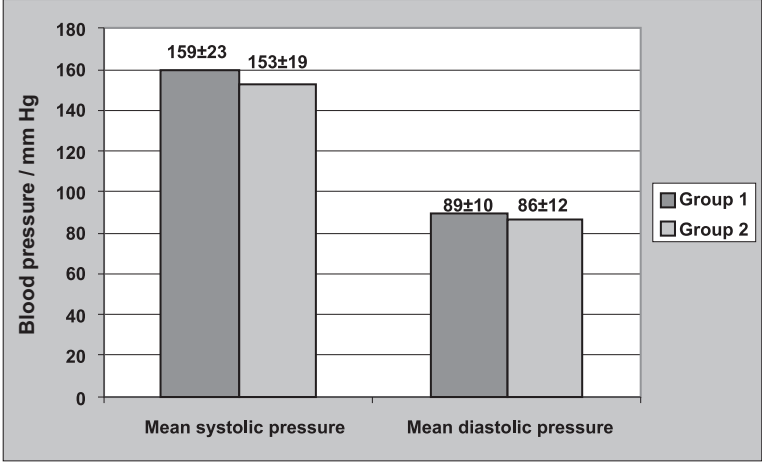

Group 1 - Miladinovci; Group 2 - Creshevo

Figure 1 Mean systolic and diastolic blood pressure by groups

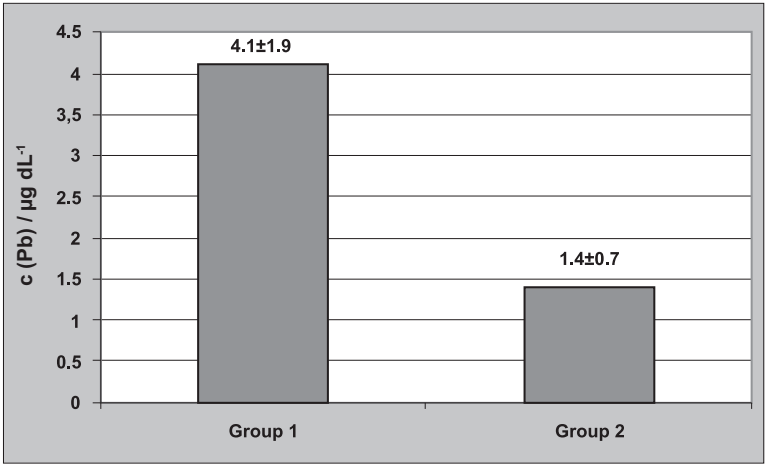

Group 1 - Miladinovci; Group 2 - Creshevo

Figure 3 Mean blood lead level by groups

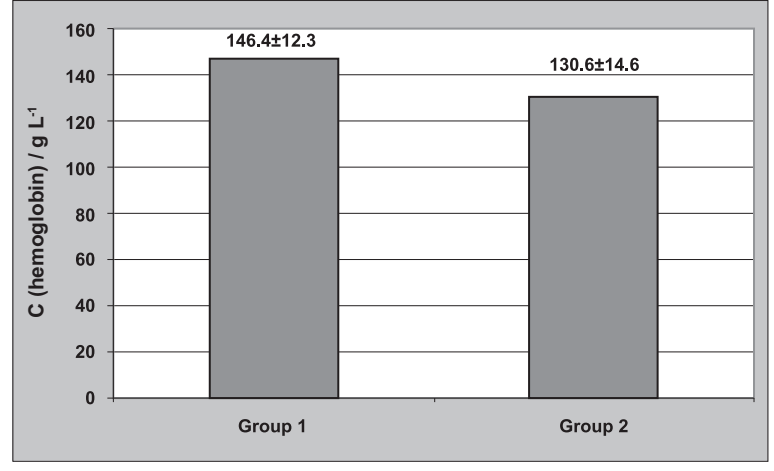

Group 1 - Miladinovci; Group 2 - Creshevo

Figure 2 Mean blood haemoglobin concentration by groups

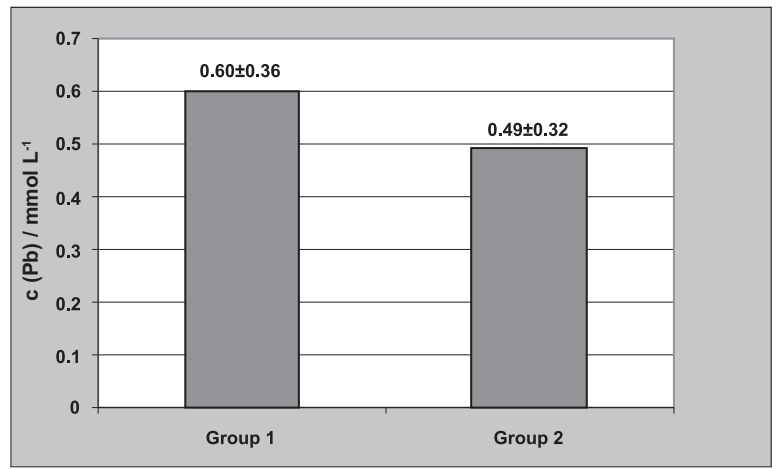

Group 1 - Miladinovci; Group 2 - Creshevo

Figure 4 Mean blood level of carbon monoxide by groups

Table 3 Exposure of examined subjects during day-to-day activities

\begin{tabular}{lccc}
\hline Exposure & $\begin{array}{c}\text { Group 1 - Miladinovci } \\
(\mathbf{n = 6 0 )}\end{array}$ & $\begin{array}{c}\text { Group 2 - Creshevo } \\
\mathbf{( n = 5 9 )}\end{array}$ & $\boldsymbol{p}$-value* \\
& $\mathbf{N}(\mathbf{\%})$ & $\mathbf{N}(\mathbf{\%})$ & 0.648 \\
\hline Noise & $2(3.3)$ & $3(5.1)$ & 0.648 \\
Local vibrations & $2(3.3)$ & $3(5.1)$ & 0.963 \\
Dampness & $33(55.0)$ & $32(54.2)$ & 0.844 \\
Draft & $57(95.0)$ & $59(100)$ & 0.896 \\
High temperature & $58(96.7)$ & $59(100)$ & 0.948 \\
Low temperature & $59(98.3)$ & $59(100)$ & 0.896 \\
Climatic factors & $58(96.7)$ & $59(100)$ & 0.896 \\
Dust & $58(96.7)$ & $59(100)$ & 0.896 \\
Chemical agents & $58(96.7)$ & $59(100)$ & 1.000 \\
Contact with animals & $60(100)$ & $59(100)$ & 1.000 \\
Contact with plants & $60(100)$ & $59(100)$ & 0.948 \\
Hard muscular work & $59(98.3)$ & $59(100)$ & 0.948 \\
Loading & $59(98.3)$ & $59(100)$ & 0.896 \\
Unfavorable body position & $58(96.7)$ & $59(100)$ & 0.896 \\
Repeated hand movements Work with & $58(96.7)$ & $59(100)$ & 0.942 \\
sharp tools & $57(95.0)$ & $55(93.2)$ & \\
\hline
\end{tabular}

Data are expressed as number $(N)$ and percentage.

* Tested by chi-square test (or Fisher's exact test where appropriate). 
Table 4 Prevalence of symptoms in the last 12 months

\begin{tabular}{lccc}
\hline $\begin{array}{l}\text { Symptoms } \\
\text { in the last } \mathbf{1 2} \text { months }\end{array}$ & $\begin{array}{c}\text { Group } \mathbf{1} \text { - Miladinovci } \\
(\mathbf{n = 6 0 )}\end{array}$ & $\begin{array}{c}\text { Group 2 - Creshevo } \\
\mathbf{N}(\mathbf{\%}) \mathbf{5 9 )}\end{array}$ & $\begin{array}{c}\mathbf{p} \text {-value* } \\
\mathbf{N}(\mathbf{\%})\end{array}$ \\
\hline Skin problems & $7(11.7)$ & $5(8.5)$ & 0.601 \\
Nasal symptoms & $8(13.3)$ & $4(6.8)$ & 0.283 \\
Respiratory symptoms & $12(20.0)$ & $10(16.9)$ & 0.722 \\
Cardiovascular problems & $8(13.3)$ & $2(3.4)$ & 0.069 \\
Gastrointestinal symptoms & $15(25.0)$ & $9(15.2)$ & 0.279 \\
Osteomuscular problems & $16(26.7)$ & $10(16.9)$ & 0.314 \\
Muscle pain in the extremities & $20(33.3)$ & $8(13.6)$ & 0.044 \\
Other symptoms & $31(51.7)$ & $23(38.9)$ & 0.323 \\
Headache & $18(30.0)$ & $7(11.8)$ & 0.049 \\
Fatigue & $22(36.6)$ & $7(11.8)$ & 0.012 \\
\hline
\end{tabular}

Data are expressed as number $(N)$ and percentage.

* Tested by chi-square test (or Fisher's exact test where appropriate).

Table 5 Work-related symptoms in the study subjects

\begin{tabular}{|c|c|c|c|}
\hline Symptoms & $\begin{array}{c}\text { Group } 1 \text { - Miladinovci } \\
(\mathbf{n}=60) \\
\text { N }(\%)\end{array}$ & $\begin{array}{c}\text { Group } 2 \text { - Creshevo } \\
(\mathbf{n}=59) \\
\text { N }(\%)\end{array}$ & $p$-value* \\
\hline Back pain & $24(40.0)$ & $32(54.2)$ & 0.350 \\
\hline Muscular pain in the extremities & $16(26.7)$ & $12(20.3)$ & 0.521 \\
\hline Fatigue & $10(16.7)$ & $10(16.9)$ & 0.972 \\
\hline
\end{tabular}

Data are expressed as number $(N)$ and percentage.

* Tested by chi-square test.

Table 6 Spirometry measurements by groups

\begin{tabular}{lccc}
\hline Ventilatory capacity & $\begin{array}{c}\text { Group 1 - Miladinovci } \\
(\mathbf{n = 6 0 )}\end{array}$ & $\begin{array}{c}\text { Group 2 - Creshevo } \\
\mathbf{( n = 5 9 )}\end{array}$ & $\boldsymbol{p}$-value* \\
& $\mathbf{N}(\mathbf{\%})$ & $42(71.2)$ & 0.792 \\
Normal venilatory capacity & $46(76.6)$ & $3(5.1)$ & 0.648 \\
Restrictive ventilatory defect & $2(3.3)$ & $2(3.4)$ & 0.578 \\
Obstructive ventilatory defect & $3(5.0)$ & $3(5.1)$ & 0.674 \\
Mixed ventilatory defect & $4(6.7)$ & $10(16.9)$ & 0.363 \\
Small airways obstruction & $5(8.3)$ & & \\
\hline
\end{tabular}

Data are expressed as number ( $N$ ) and percentage.

* Tested by chi-square test (or Fisher's exact test where appropriate).

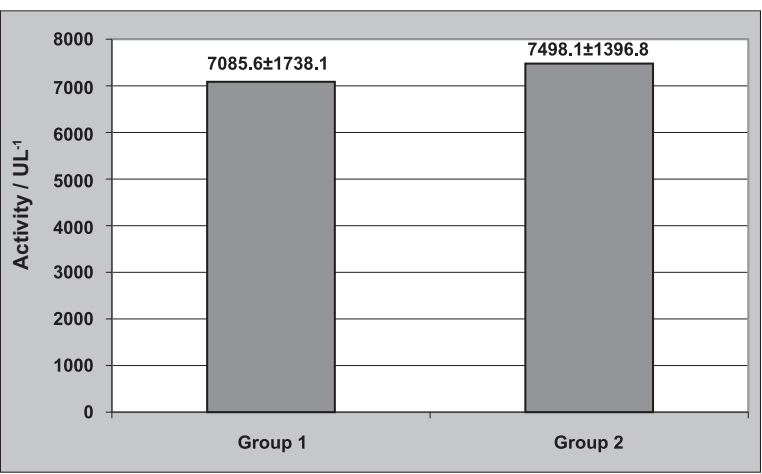

Group 1 - Miladinovci; Group 2 - Creshevo

Figure 5 Mean serum cholinesterase activity by groups
The subjects from both examined groups reported similar work-relatedness of their symptoms. All of them reported $100 \%$ availability of primary health care services and at the same time, they indicated that the occupational health services were not available in those rural communities.

In this study we did not find significant differences in the mean systolic pressure, and observed slightly, but not significantly higher mean diastolic pressure in Group 1, exposed to industrial and traffic pollutants. Results of previous study which compared cardiovascular disease risk factors in farm and 
non-farm residents (19) indicate high prevalence of risk factors for atherosclerosis, and hence future coronary heart disease rural population, especially in women. They also suggest the need for obesity prevention through increased physical activity and quit smoking campaigns (19). Another study (20) showed significantly increased number of cases with systolic and diastolic hypertension in the mountain regions. The incidence of hypertension among women was higher than among men.

Although we did not find significant differences regarding to the spirometry results, previous study (21) on French diary farmers showed that dairy farming is associated with an excess of chronic bronchitis, with a moderate degree of bronchial obstruction and a mild decrease in $\mathrm{SpO}_{2}(21)$. According to a study of farmers in Denmark, the prevalence of wheezing was $18.2 \%$, of asthma $7.7 \%$, and of chronic bronchitis $23.6 \%(22)$.

Our results regarding haematological parameters (blood haemoglobin concentration, mean red cells count) were in accordance with the study (23) dedicated to occupational exposure and pesticide poisoning among cut-flower farmers in Philippines, which reported abnormal haemoglobin/haematocrit concentration, and eosinophil count.

In the Miladinovci group, exposed to industrial and traffic pollutants we found significantly elevated BLL. About $2 \%$ of subjects in that group had elevated blood lead levels, as compared to the Creshevo group, where none of the study subjects had levels above reference value of $10 \mu \mathrm{g} \mathrm{dL}^{-1}$. A major predictor of elevated BLLs in this area can be attributed to exposure to airborne lead emissions from vehicles on cross-road and a highway overpass. Similar results were found in Mexican farm workers in eastern North Carolina, whose BLLs exceeded reference values (24). Among them age and pack years of cigarette smoking were stressed as more important predictors of lead exposure, compared to years worked in agriculture.

Relatively low levels of lead exposure may cause adverse effects on cardiovascular and renal function in adults. A 2007 study by Spivey about lead effects in adults (25) showed that elderly people had high deposition and retention rates and were more susceptible to lead exposure. In a study of environmental and occupational lead exposure in Nairobi, Kenya, BLLs ranged from $0.4 \mu \mathrm{g} \mathrm{dL}^{-1}$ to $65 \mu \mathrm{g} \mathrm{dL}^{-1}$. In an area with environmental exposure they ranged from $1.4 \mu \mathrm{g} \mathrm{dL}^{-1}$ to $22.0 \mu \mathrm{g} \mathrm{dL}^{-1}(26,27)$. These findings are similar to our results and confirm the correlation between geographical distribution of BLLs and environmental exposure.

Health risks for the Miladinovci group studied here partly originated form the petroleum refinery. During their technological operations, refineries generate huge amounts of oily sludge, bio-sludge and chemical sludge. For instance, Indian refineries generate about 28,220 tons of sludge per year (28). Various types of pollutants like phenols, heavy metals, etc. are present in the sludge and they are treated as hazardous waste.

Although intense industrial activities and traffic are often sources of air pollution, the Yearly Report of the Ministry for Ecology and Urban Planning of R. Macedonia for 2009, suggest that the average annual concentration of nitrogen dioxide, carbon monoxide, ammonia, and sulphur dioxide measured in Miladinovci were within the reference range (29). Only the average annual concentration for 2009 of the PM10 was above the reference values (29).

As an EU candidate country, Macedonia has phased out lead (tetraethyl lead) as a gasoline additive since 2008. Over time, reducing the use of lead additives in gasoline/petrol in motor vehicles has been quite effective in diminishing, the lead content in used motor oil. This has proven to be a very significant and efficient way to minimize the risks of used motor oil, particularly used oil burned for energy where lead emissions are often of concern (29).

In the Miladinovci group, exposed to industrial and traffic pollutants, we also found slightly elevated mean blood carbon monoxide. Previous report (30) suggest that intensive livestock production facilities can provide high ambient levels (up to $136 \mathrm{mg} \mathrm{m}^{-3}$ ) of carbon monoxide and high levels of carboxyhemoglobin in both animals and workers.

Mean serum cholinesterase activity in our study was similar in both groups. A reduction of serum cholinesterase activity indicate a higher risk of pesticide poisoning, and therefore monitoring of serum cholinesterase activity is a useful tool to predict and prevent health hazards of pesticides. A study in Pakistan (31) showed that cholinestrase activity in tobacco farmers was significantly lower than in controls. Our findings may refer to the fact that both examined groups were involved in agriculture as a basic occupational activity; thus, the differences in environmental exposure did not make significant influence in the obtained data about the mean serum cholinesterase activity.

Our study has some limitations. The first is a relatively small number of subjects, which may 
have certain implications on interpretation of data. Secondly, interpretation may also be clouded by the fact that both groups were involved in similar agricultural activities with similar occupational risks. Thirdly, the study lacks specific environmental monitoring data relevant for evaluating adverse health effects. On the other hand, this study is among the few to try to assess health effects of environmental factors in worker population. Its strength is that by extensive subject examination it has made it possible to compare our results with other studies.

In addition, our study addresses an important issue about the coverage of rural population by health services. There is an evident discrepancy between quality of life, sanitation, income, and distribution of welfare benefits, including occupational health services, between the rural and urban population, even in the developed countries (2). Rural population in Macedonia has a good access to primary health care by general practitioners. However, agricultural workers require additional health surveillance (3), as GPs can not provide the full spectrum of services they need, and which should include occupational health and safety (4).

With the basic occupational health services (BOHS), Macedonia should be able to address vulnerable groups of workers and high risk sectors, including agriculture. The BOHS concept, promoted by the WHO Global Plan of Action on Workers Health for 2008-2017, should provide basic protection at work and promotion of health, well-being, and work ability within the frame of primary health care (32).

Improvement of health status in rural population requires a multidimensional approach and cooperation aimed at promoting physical, mental, and social wellbeing. It should involve intensive education of rural population about occupational health risks and of healthcare workers in rural areas through workshops, seminars, and training.

\section{CONCLUSION}

Our results can be used to prioritise, target, and develop effective prevention strategies in rural communities. Our findings indicate the need of regular medical exams, ambient monitoring and environmental impact assessment in agricultural population in order to detect individuals at risk and to institute adequate preventive measures.

Improvement of work conditions, regular health surveillance, and availability of occupational health services are the prevention essentials. Instrumental to this objective in Macedonia is the promotion of BOHS within the frame of primary health care.

\section{REFERENCES}

1. Census of Agriculture 2007. State Statistical Office of R. Macedonia [displayed 8 November 2010]. Available at: http:// www.stat.gov.mk/english/PopisNaZemjodelstvoto2007/ opsto_eng.asp.

2. International Labour Organization (ILO). The ILO Programme on Occupational Safety and Health in Agriculture [displayed 8 November 2010]. Available at http://www.ilo. org/safework/areasofwork/lang--en/WCMS_117367/index. htm

3. Ministry of Health of R. Macedonia. Program for analysis and prevention of occupational risks in rural population in R. Macedonia. Official Gazette of R. Macedonia 03/2009.

4. Colosio C, Ariano E, Patil A. Lodi Declaration on Healthy Villages: adopted by the $16^{\text {th }}$ International Congress of Agricultural Medicine and Rural Health, Lodi, Italy, 18-21 June 2006. Med Lav 2006;97:814-5.

5. US Department of Energy, Office of Industrial Technologies. Energy and Environmental Profile of the US Petroleum Refining Industry 1998 [displayed 8 November 2010]. Available at http://www.inti.gov.ar/cadenasdevalor/energia. pdf.

6. US Environmental Protection Agency (US EPA). Air Quality Criteria for Lead (Final, 1986). [displayed 23 November 2010]. Available at http://cfpub.epa.gov/ncea/ $\mathrm{cfm} /$ recordisplay.cfm?deid=32647\#Download.

7. Godson REEA, Mynepalli KCS. Industrial emissions and health hazards among selected factory workers at Eleme, Nigeria. J Environ Health Res 2006;9:43-51.

8. Venn A, Yemaneberhan H, Lewis S, Parry E, Britton J: Proximity of the home to roads and the risk of wheeze in an Ethiopian population. Occup Environ Med 2005;62:37680.

9. Bayer-Oglesby L, Schindler C, Hazenkamp-von Arx M, Braun-Fahrlander C, Keidel D, Rapp R, Kunzli N, Braendli O, Burdet L, Liu S, Leuenberger P, Ackermann-Liebrich U, the SAPALDIA team. Living near main streets and respiratory symptoms in adults. Am J Epidemiol 2006;164:1190-8.

10. Lin CA, Pereira LAA, de Souza Conceicao GM, Kishi HS, Milani RJ, Braga ALF, Saldiva PHN. Association between air pollution and ischemic cardiovascular emergency room visits. Environ Res 2003;92:57-63.

11. Raaschou-Nielsen O, Hertel O, Thomsen BL, Olsen JH. Air pollution from traffic at the residence of children with cancer. Am J Epidemiol 2001;153:433-43.

12. White AJ, Gompertz S, Stockley RA. Chronic obstructive pulmonary disease 6: The aetiology of exacerbations of chronic obstructive pulmonary disease. Thorax 2003;58:7380.

13. Pickering TG, Hall JE, Appel LJ, Falkner BE, Graves J, Nill MN, Jones DW, Kurtz T, Sheps SG, Roccella EJ. AHA Scientific Statement. Recommendations for Blood Pressure Measuerment in Humans and Animals. Part 1: Blood Pressure Measurement in Humans: A Statement for Professionals from the Subcommittee of Professional and Public Education of 
American Heart Association Council on High Blood Pressure Research. Hypertension 2005;45:142.

14. Quajner PH, editor. Standardization of Lung Function Tests - 1993 Update. Report Working Party for the European Community for Steel and Coal. Official Statement of the European Rrespiratory Society. Eur Respir J 1993;3(Suppl 16):1-100.

15. ESA LeadCare ${ }^{\circledR}$ Blood lead test kit [displayed 24 April 2010]. Available at http://www.waivedleadcare.com.

16. Linderholm $\mathrm{H}$. A micromethod for the determination of carbon monoxide in blood. Acta Physiol Scand 1965;64:3726.

17. Osawa S, Kariyone K, Ichihara F, Arai K, Takagasa N, Ito $\mathrm{H}$. Development and application of serum cholinesterase activity measurement using benzoylthiocholine iodide. Clin Chim Acta 2005;351:65-72.

18. Slesinger DP. Health status and needs of migrant farm workers in the United States: a literature review. J Rural Health 1992;8:227-34.

19. McCarty C, Chyou PH, Ziegelbauer L, Kempf D, McCarty D, Gunderson P, Reding D. A comparison of cardiovascular disease risk factors in farm and non-farm residents: the Wisconsin Rural Women's Health Study. WMJ 2002;101:34-

20. Olziǐkhutag A, Dondog N, Batmunkh G. [Arterial pressure in cattle breeders living in different climatic and geographic zones of Mongolia, in Russian]. Kardiologiia 1979;19:58 62.

21. Chaudemanche H, Monnet E, Westeel V, Pernet D, Dubiez A, Perrin C, Laplante J-J, Depierre A, Dalphin J-C. Respiratory status in dairy farmers in France; cross sectional and longitudinal analyses. Occup Environ Med 2003;60:85863.

22. Iversen M, Dahl R, Korsgaard J, Hallas T, Jensen EJ Respiratory symptoms in Danish farmers: an epidemiological study of risk factors. Thorax 1998;43:872-7.
23. Leilanie J. Acute pesticide poisoning among cut-flower farmers: a cross sectional study. J Environ Health 2007;2:3843.

24. Quandt SA, Jones BT, Talton JW, Whalley LE, Galván L, Vallejos QM, Grzywacz JG, Chen H, Pharr KE, Isom S, Arcury TA. Heavy metals exposures among Mexican farm workers in eastern North Carolina. Environ Res 2010;110:838.

25. Spivey A. The weight of lead: Effects add up in adults. Environ Health Perspect 2007;115:A30-6.

26. von Schirnding YER, Mathee A, Robertson P. Distribution of blood lead levels in school children in selected Cape Peninsula suburbs subsequent to reductions in petrol lead. South Afr Med J 2001;91:870-2.

27. Njoroge GK, Njagi ENM, Orinda GO, Sekadde-Kigondu CB, Kayima JK. Environmental and occupational exposure to lead. East Afr Med J 2008;85:284-91.

28. Bhattacharyya JK, Shekdar AV. Treatment and disposal of refinery sludges: Indian scenario. Waste Manag Res 2003;21:249-61.

29. Yearly Report on the quality of environment 2009. Ministry of environment and physical planning. [displayed 23 November 2010]. Available at: http://www.moepp.gov.mk/ WBStorage/Files/Godisen\%20VOZDUH\%202009.pdf.

30. US Environmental Protection Agency (US EPA). Significant Harm Levels for Carbon Monoxide, Draft. [displayed 23 November 2010]. Available at http://nepis.epa.gov/.

31. Khan DA, Bhatti MM, Khan FA, Naqvi ST, Karam A. Adverse effects of pesticides residues on biochemical markers in pakistani tobacco farmers. Int J Clin Exp Med 2008; 1:274-82.

32. World Health Organization (WHO). Workers' health: global plan of action. Sixtieth World Assembly, WHA60.26, 2007 [displayed 8 November 2010]. Available at http://apps.who. int/gb/ebwha/pdf_files/WHA60/A60_R26-en.pdf. 


\section{Sažetak \\ OKOLIŠNI I PROFESIONALNI RIZICI ZA ZDRAVLJE POLJOPRIVREDNIH RADNIKA KOJI ŽIVE BLIZU RAFINERIJE NAFTE I AUTOCESTE NEDALEKO OD SKOPJA}

Cilj je ovoga presječnog ispitivanja bio ocijeniti zdravstveni rizik u 119 nasumce izabranih poljoprivrednih radnika povezan s izloženosti onečišćivačima čiji su izvori rafinerija nafte odnosno promet. Prva skupina ispitanika obuhvatila je 60 poljoprivrednika s prebivalištem u Miladinovcima, u blizini rafinerije nafte i nadvožnjaka autoceste, dok je druga skupina obuhvatila 59 poljoprivrednika iz Creševa, koji su obavljali slične djelatnosti, ali nisu bili izloženi industrijskim i prometnim onečišćivačima. Ocjena rizika obuhvatila je odgovore na upitnik, krvni tlak, spirometriju te nalaze laboratorijskih i toksikoloških pretraga. Obje su skupine iskazale podjednaku prevalenciju zdravstvenih tegoba, a izuzetak je značajno veća učestalost boli u mišićima, glavobolje i umora u skupini iz Miladinovaca. Dijastolički krvni tlak i ugljikov monoksid u krvi također su bili viši u ovoj skupini, ali se nisu značajno razlikovali od skupine iz Creševa ( $p=0,057)$. Značajno više u skupini iz Miladinovaca bile su međutim razine hemoglobina $(p=0,001)$ i olova u krvi $(\mathrm{p}<0.001)$. Aktivnost kolinesteraza u serumu bila je podjednaka u obje skupine. Naši rezultati upućuju na štetno djelovanje izloženosti onečišćivačima iz naftne rafinerije i prometa u poljoprivrednika te na potrebu za redovitim liječničkim pregledima radi prepoznavanja ugroženih pojedinaca te za uvođenjem odgovarajućih preventivnih mjera.

KLJUČNE RIJEČI: krvni tlak, okolišna izloženost, hemoglobin, selo, toksikološka analiza

\section{CORRESPONDING AUTHOR:}

Professor Jovanka Karadžinska-Bislimovska, MD, PhD

Institute for Occupational Health of R. Macedonia

WHO Collaborating Center for Occupational Health

II Makedonska Brigada 43,1000 Skopje,

Republic of Macedonia

E-mail:bislimovskaj@yahoo.com 